\title{
Electrical Stunning sebelum Penyembelihan dapat Menurunkan Serum Superoxide Dismutase Babi Landrace Crossbred
}

\section{Electrical Stunning before Slaughter Alleviate Superoxide Dismutase Serum in Landrace Crossbred Pigs}

\author{
Shabrina Fauzia Prayoga ${ }^{1}$, Faisal Fikri ${ }^{2}$, Muhammad Thohawi Elziyad Purnama ${ }^{1 *}$ \\ ${ }^{1}$ Departemen Anatomi Veteriner, ${ }^{2}$ Departemen Ilmu Kedokteran Dasar Veteriner, \\ Fakultas Kedokteran Hewan, Universitas Airlangga \\ *Correponding Author, Email: thohawi@fkh.unair.ac.id
}

Naskah diterima: 16 Januari 2020, direvisi: 16 Juli 2020 , disetujui: 30 Juli 2020

\begin{abstract}
This study aimed to evaluate the Superoxide Dismutase (SOD) in Landrace Crossbred pigs were stunned using electrical stunning and without stunning before slaughter. A total of 18 castrated adult male Landrace Crossbred pigs, weighty $115 \pm 20 \mathrm{~kg}$ divided into two treatments, i.e. electrical stunning and without stunning with serum determination at pre and post treatment. $3 \mathrm{ml}$ blood sample were taken, then SOD activity was performed using StressXpress ${ }^{\circledR}$ kit. The SOD level was tested for normality using Shapiro-Wilk Test, followed by the Univariate Linear Model test to compare serum SOD between electrical stunning and without stunning at the pre and post treatment phases. The results of the Shapiro-Wilk Test supported the Q-Q plot diagram showed a normal distribution in all treatments. The electrical stunning showed a significantly alleviated of SOD level. In addition, SOD level was also significant alleviate in pre-treatment compared to post-treatment. In conclusion, there was a significantly decreased in the SOD activity of Landrace Crossbred pig serum stunned with electrical stunning before slaughter.
\end{abstract}

Key words: electrical stunning; Landrace Crossbred pig; Superoxide dismutase;

\begin{abstract}
Abstrak
Penelitian bertujuan untuk mengevaluasi enzim Superoxide Dismutase (SOD) pada serum babi Landrace Crossbred yang mendapat electrical stunning dan tanpa electrical stunning sebelum penyembelihan. Sebanyak 18 ekor babi Landrace Crossbred jantan dewasa kebiri dan bobot $115 \pm 20 \mathrm{~kg}$ dibagi menjadi dua perlakuan, yakni electrical stunning dan tanpa electrical stunning dengan pengujian serum pada pre dan post perlakuan. Sebanyak $3 \mathrm{ml}$ sampel darah diambil dan diuji kadar SOD dengan StressXpress ${ }^{\circledR}$ kit. Pembacaan kadar SOD diuji normalitas dengan Shapiro-Wilk Test, diilanjutkan uji Univariate Linear Model untuk membandingkan kadar SOD antara electrical stunning dan tanpa electrical stunning pada fase pre dan post perlakuan. Hasil ShapiroWilk Test dengan diagram Q-Q plot menunjukkan pola distribusi normal pada semua perlakuan. Kelompok electrical stunning menunjukkan penurunan signifikan SOD. Kadar SOD yang rendah tampak signifikan juga pada pre perlakuan dibandingkan dengan post perlakuan. Dapat disimpulkan terdapat penurunan signifikan SOD pada serum babi Landrace Crossbred yang mendapat electrical stunning sebelum penyembelihan.
\end{abstract}

Kata kunci: babi Landrace Crossbred; electrical stunning; Superoxide dismutase 


\section{Pendahuluan}

Penyembelihan secara umum merupakan tindakan untuk menghilangkan nyawa hewan menggunakan benda tajam dengan syarat terpotong trachea, esophagus, vena jugularis dan arteri carotis communis, sedangkan pada babi dilakukan dengan cara menusuk bagian leher ke arah anterior sternum yakni area pembuluh darah besar dan jantung (Dannar, 2015; Goba, 2013). Penyembelihan harus dilakukan dengan cepat untuk meminimalkan rasa sakit dan stres pada hewan yang dapat mempengaruhi kualitas daging (Chulayo dkk., 2012). Metode penyembelihan dapat dilakukan dengan cara pemingsanan (stunning) dan tanpa pemingsanan.

Menurut Zivotofsky dan Strous (2012), stunning adalah perlakuan yang bertujuan untuk memingsankan hewan sebelum penyembelihan. Stunning dilakukan untuk memudahkan imobilisasi hewan yang akan disembelih dan menjamin keamanan petugas pemotongan hewan (BergeaudBlackler, 2007). Tujuan stunning adalah untuk meminimalkan rasa sakit, takut dan stres pada hewan selama proses penyembelihan yang dapat mempengaruhi kualitas daging (Gregory, 2007; Hindle dkk., 2010).

Stunning dilakukan dengan metode elektrik, mekanis maupun menggunakan gas (OIE, 2011). Electrical stunning dilakukan dengan alat penjepit yang dialirkan listrik di kepala atau tubuh hewan, secara mekanis dilakukan dengan menggunakan captive bolt stun gun sedangkan stunning dengan gas dilakukan menggunakan paparan gas dengan kadar $80-90 \%$ selama 3 menit (EFSA, 2006; OIE, 2011). Hewan yang biasa disembelih dengan metode stunning salah satunya adalah babi. Stunning secara mekanis pada babi, selain menggunakan captive bolt stun gun juga dilakukan dengan memukul daerah dahi menggunakan balok kayu (Goba, 2013).

Penyembelihan dengan stunning dan tanpa stunning merupakan isu animal welfare yang sering diperdebatkan. Hewan yang disembelih tanpa stunning dapat merasakan sakit dan menderita selama hewan tersebut belum benar-benar hilang kesadaran, sehingga stunning dianggap sebagai metode penyembelihan yang lebih sesuai dengan animal welfare (Kim dkk., 2013; Farouk dkk., 2014). Menurut Adzitey (2011), stunning juga dapat mengakibatkan stres apabila dilakukan secara tidak tepat, seperti akibat operator (stunner) yang kurang terlatih atau alat stunning yang berfungsi kurang baik.

Metode penyembelihan memegang peran penting dalam menentukan kualitas daging dan dapat mempengaruhi metabolisme otot post mortem (Sabow dkk., 2015; Bourguet dkk., 2011). Metode penyembelihan yang kurang baik dapat menyebabkan stres sebelum pemotongan (preslaughter stress). Pre-slaughter stress merupakan salah satu faktor yang dapat mempengaruhi kualitas daging karena dapat mengakibatkan daging Dark Firm Dry (DFD) maupun Pale Soft Oxydative (PSE) (Rosenvolt dan Andersen, 2003). Studi lebih lanjut perlu dilakukan untuk dapat memberikan gambaran mengenai perbandingan tingkat stres yang dialami hewan yang disembelih dengan metode stunning dan tanpa stunning, sehingga dapat diketahui metode penyembelihan yang efektif dan dapat menghasilkan daging dengan kualitas yang baik.

Superoxide dismutase (SOD) merupakan salah satu biomarker yang dapat digunakan untuk mengetahui stres hewan. Aktivitas SOD memiliki peran penting dalam adaptasi tubuh terhadap stres yakni melalui proses degradasi Reactive Oxygen Spesies (ROS) (Surai, 2016). Mekanisme stres dapat ditandai dengan peningkatan produksi ROS dan aktivitas antioksidan eksogen seperti SOD (Del Rio, 2005). Penelitian ini bertujuan untuk menguji pengaruh electrical stunning terhadap aktivitas SOD serum sebagai indikator preslaughter stress pada babi Landrace Crossbred.

\section{Materi dan Metode}

\section{Uji Etik Penelitian}

Penelitian dilakukan di peternakan dan rumah pemotongan babi Pegirian, Surabaya. Prosedur handling dan restraint untuk babi yang disembelih dengan stunning dan tanpa stunning selama penelitian sesuai dengan diagram alir Standard Operasional Prosedur (SOP) No.313/ SOP/UDRPH/V/2017 yang diterbitkan oleh Kepala Bagian Pemotongan Rumah Potong Hewan Surya Pegirian Surabaya. Ijin penelitian didapat dari Badan Kesatuan Bangsa dan Politik Kota Surabaya. Uji etik penelitian didapatkan dari 
Komite Etik dan Penggunaan Hewan Coba Fakultas Kedokteran Hewan, Universitas Airlangga dengan nomor registrasi 686-KE.

\section{Perlakuan Babi}

Jenis penelitian adalah penelitian eksperimental dengan rancangan pre-post test group design. Babi dipilih secara random sesuai dengan kriteria, yakni babi jantan dewasa yang telah dikebiri, breed Landrace Crossbred, dan bobot badan $115 \pm 20 \mathrm{~kg}$.

Babi sejumlah 18 ekor dibagi menjadi dua kelompok, yakni 9 ekor kelompok dengan stunning dan 9 ekor kelompok tanpa stunning. Masingmasing kelompok perlakuan diambil serum darah pre dan post perlakuan. Metode penyembelihan yang dilakukan adalah penyembelihan dengan electrical stunning dan tanpa stunning. Electrical stunning merupakan metode stunning yang dilakukan dengan mengaliri listrik pada dua elektroda yang dipasang di kepala hewan. Standard umum yang digunakan untuk electrical stunning pada babi berusia lebih dari enam minggu adalah 220 Volt dan 1.3 Ampere (Pleiter, 2010). Penyembelihan tanpa stunning merupakan penyembelihan yang tidak didahului dengan pemingsanan, pada babi yang dilakukan dengan cara menusuk bagian leher ke arah anterior sternum yakni area pembuluh darah besar dan jantung (Goba, 2013).

\section{Pengambilan Serum dan Pengujian SOD}

Sampel darah pre perlakuan diambil pada bagian Vena auricular sedangkan post perlakuan diambil pada bagian Vena jugularis atau pancaran pertama setelah ditusuk. Sampel darah diambil minimal sebanyak $3 \mathrm{ml}$, kemudian dimasukkan ke dalam vacutainer plain $5 \mathrm{ml}$ dan diberi label. Label berisi keterangan, yakni perlakuan dan kode pemotongan babi. Pengambilan darah dilakukan secara aseptis dengan peralatan steril untuk menghindari pencemaran bakteri dan hemolisis.

Sampel darah didiamkan pada suhu ruang selama 1-2 jam hingga serumnya terpisah kemudian disentrifus dengan kecepatan $6.000 \mathrm{rpm}$ selama 15 menit menggunakan sentrifuge (Hettich ${ }^{\circledR}$ EBA 20). Serum adalah lapisan jernih berwarna kuning muda yang berada di bagian atas tabung (Putra dkk., 2012). Serum yang didapat kemudian dipindahkan ke dalam microtube menggunakan micropipette dan yellow tip, kemudian disimpan pada suhu $4^{\circ} \mathrm{C}$ di dalam cool box yang berisi ice gel.

Pengukuran aktivitas SOD dilakukan dengan menggunakan StressXpress ${ }^{\circledR}$ SOD Activity Kit. Menurut StressMarq Bioscience Inc. (2019), langkah pengujian aktivitas SOD diawali dengan membuat larutan standard terlebih dahulu sebanyak enam tabung. Enzim SOD sebanyak $250 \mu \mathrm{L}$ digunakan sebagai larutan stock dengan aktivitas SOD $4 \mathrm{U} / \mathrm{mL}$. Pengenceran larutan standard selanjutnya adalah dilakukan dengan menambahkan Buffer Assay sebanyak $75 \mu \mathrm{L}$ hingga didapat larutan standard dengan aktivitas SOD 2 U/ $\mathrm{mL}, 1 \mathrm{U} / \mathrm{mL}, 0.5 \mathrm{U} / \mathrm{mL}, 0.25 \mathrm{U} / \mathrm{mL}, 0.125 \mathrm{U} / \mathrm{mL}$ dan $0.0625 \mathrm{U} / \mathrm{mL}$. Persiapan reagen meliputi pembuatan Xanthine Oxidase dan Substrat.

Serum hasil koleksi sampel dan setiap konsentrasi larutan standard SOD dipindahkan sebanyak $10 \mu \mathrm{L}$ ke dalam microplate 96 well. Pindahkan pula $10 \mu \mathrm{L}$ Buffer Assay sebagai Zero Standard. Setiap sumuran ditambahkan $50 \mu \mathrm{L}$ substrat dan $25 \mu \mathrm{L}$ Xanthine Oxidase, lalu diinkubasi di suhu ruang selama 20 menit. Microplate tersebut kemudian dibaca nilai optical density (OD) dengan $\lambda=430 \mathrm{~nm}$ menggunakan spectrophotometer Nilai penghambatan didapatkan dari persentase absorbance OD sampel dibandingkan dengan absorbance OD standard (blanks). Selanjutnya aktivitas SOD dapat dihitung dengan rumus berikut:

Nilai Penghambatan $=\frac{\text { OD Sampel }}{\text { OD } \text { Zero Standar }} \times 100$

Aktivitas SOD = Nilai Penghambatan $\mathrm{x}$ Faktor pengenceran

\section{Analisis Data}

Hasil aktivitas SOD diuji normalitas dengan Shapiro-Wilk Test untuk melihat homogenitas data. Dilanjutkan uji Univariate Linear Model untuk membandingkan aktivitas SOD serum antara stunning dan tanpa stunning pada fase pre dan post perlakuan. Selisih kadar SOD $(\Delta \mathrm{SOD})$ antara stunning dan tanpa stunning pada fase pre dan post perlakuan diuji dengan $T$ independen sample test. Analisis data dilakukan dengan program SPSS v23 for Windows (IBM, USA).

\section{Hasil dan Pembahasan}

Berdasarkan hasil Shapiro-Wilk Test diperkuat diagram Q-Q plot distribusi normal ( $p>0.05)$ pada 
Tabel 1. Rata-rata dan standard deviasi aktivitas SOD babi pada setiap fase perlakuan

\begin{tabular}{lcccc}
\cline { 2 - 5 } & Pre perlakuan & Post perlakuan & $\Delta$ SOD & p-value \\
\hline Stunning & $96.13^{\mathrm{a}} \pm 48.35$ & $152.25^{\mathrm{c}} \pm 25.17$ & $56.12 \pm 54.47$ & 0.012 \\
Tanpa stunning & $140.45^{\mathrm{b}} \pm 77.79$ & $278.29^{\mathrm{d}} \pm 87.61$ & $137.84 \pm 66.63$ & \\
\hline
\end{tabular}

a,b,c,d Superskrip berbeda pada kolom yang sama menunjukkan perbedaan signifikan $(\mathrm{p}<0.05)$

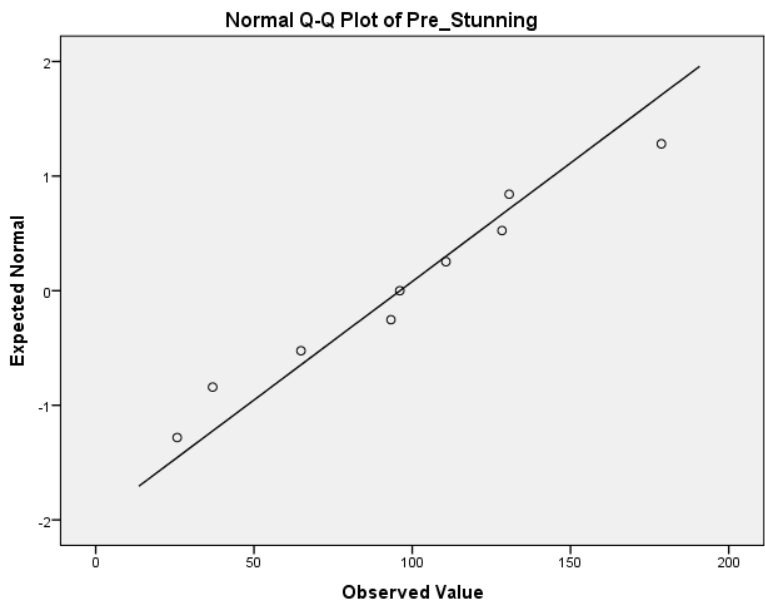

(a)

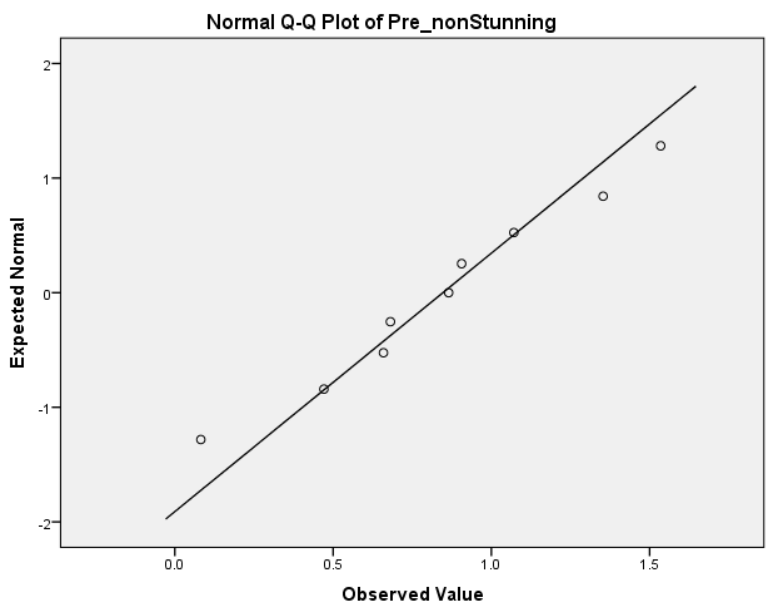

(c)

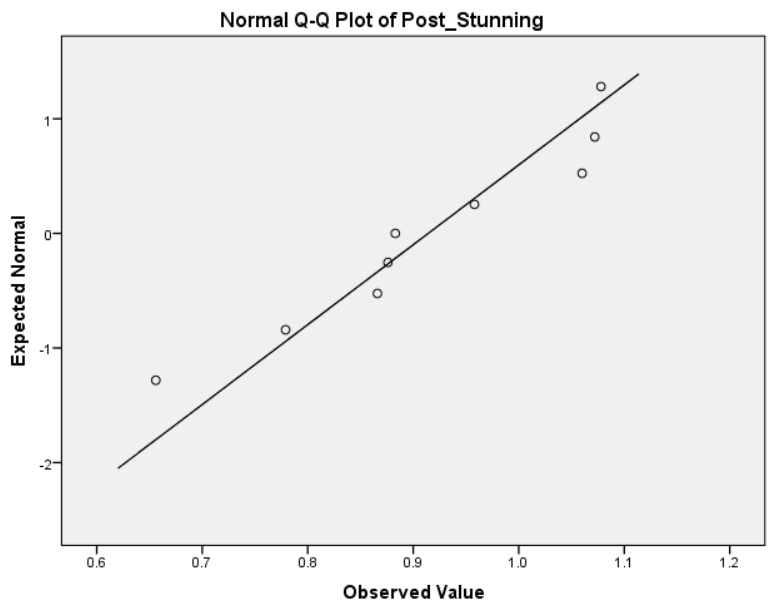

(b)

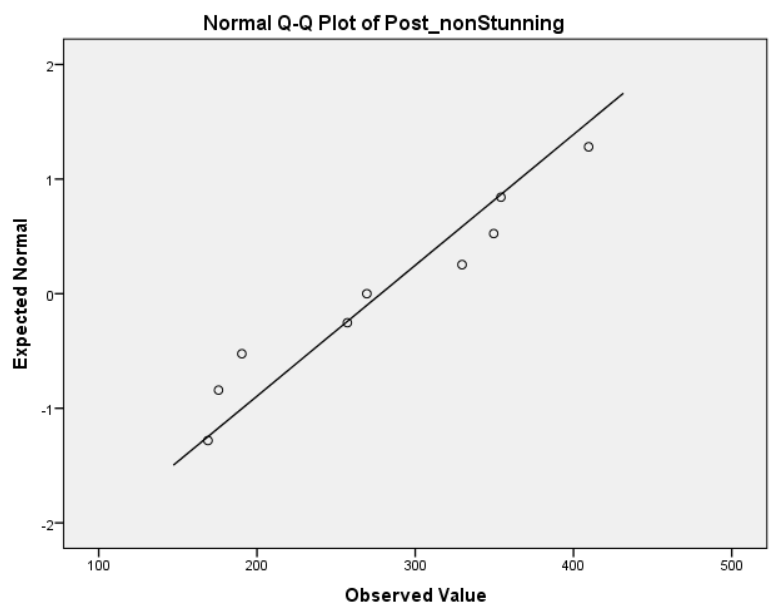

(d)

Gambar 1. Pola distribusi aktivitas SOD babi pada setiap fase perlakuan

semua perlakuan (Gambar 1). Hasil stunning menunjukkan rendahnya aktivitas SOD berbeda signifikan $(\mathrm{p}<0.05)$ dengan tanpa stunning. Aktivitas SOD yang rendah tampak berbeda signifikan $(p<0.05)$ juga pada pre perlakuan dibandingkan dengan post perlakuan (Tabel 1).

Stunning merupakan salah satu titik kritis dalam proses penyembelihan. Stunning tidak hanya berpengaruh terhadap aspek animal walfare, tetapi juga dapat mempengaruhi kualitas daging (Warner dkk., 2010). Tujuan stunning adalah meminimalkan rasa sakit selama proses penyembelihan dan memudahkan imobilisasi hewan, sehingga proses penyembelihan menjadi lebih mudah dan aman (Gregory, 2007; Sabow dkk., 2018).

Stres akibat rasa sakit selama proses penyembelihan merupakan paparan stres yang dapat diklasifikasikan sebagai paparan stres akut. Menurut Hu dkk. (2019), stres akut dapat ditandai dengan peningkatan produksi ROS yang diikuti dengan peningkatan aktivitas SOD. Tingkat stres yang dialami babi Landrace Crossbred yang disembelih dengan metode electrical stunning dan tanpa stunning pada penelitian ini dapat diketahui dengan membandingkan aktivitas SOD serum. Peningkatan stress oksidatif berdasarkan variabel kadar kortisol, SOD, MDA dan GPx juga tampak 
pada serum babi yang disembelih tanpa electrical stunning (Purnama, 2020).

Perlakuan electrical stunning dilakukan oleh stunner dengan memasangkan dua elektroda di bagian kepala tepatnya di antara mata dan pangkal telinga, dilakukan ketika posisi babi berdiri di atas palungan tanpa menggunakan alat handling maupun restrain dengan interval waktu stunning 3-5 detik sesuai SOP Penyembelihan. Penyembelihan dilakukan ketika hewan telah memasuki fase kedua yakni fase kronik. Perlakuan tanpa stunning dilakukan oleh petugas penyembelihan dengan memasukkan babi ke kandang besi kemudian diikat bagian rahangnya dan ditarik ke arah belakang hingga tubuh babi berhimpitan dengan bagian belakang kandang besi sesuai dengan SOP Penyembelihan. Metode penyembelihan pada kedua kelompok perlakuan dilakukan dengan cara yang sama yakni dengan menusuk area leher menuju ke arah jantung.

Berdasarkan hasil analisis data, terdapat perbedaan yang signifikan antara kelompok yang diberi perlakuan electrical stunning dengan tanpa stunning. Kelompok yang diberi perlakuan electrical stunning memiliki mean aktivitas SOD $152.249 \mathrm{ng} / \mathrm{mL}$, sedangkan kelompok yang diberi perlakuan tanpa stunning memiliki mean aktivitas SOD $278.292 \mathrm{ng} / \mathrm{mL}$. Aktivitas SOD serum babi Landrace Crossbred yang diberi perlakuan electrical stunning lebih rendah dibanding yang disembelih dengan tanpa stunning dengan selisih mean aktivitas SOD sebesar $126.043 \mathrm{ng} / \mathrm{mL}$, sehingga dapat disimpulkan bahwa tingkat stres yang dialami babi Landrace Crossbred yang disembelih dengan electrical stunning lebih rendah dibanding yang disembelih dengan tanpa stunning.

Menurut HSA (2016), sakit tidak dirasakan pada penyembelihan electrical stunning karena arus listrik yang melalui otak dan menyebabkan gangguan aktivitas otak, sehingga hewan kehilangan kesadaran dan tidak peka terhadap rasa sakit. Electrical stunning menyebabkan hewan mengalami grand mal epileptic atau kejang tonikkronik yang terjadi dalam tiga fase yakni tonik, kronik dan recovery. Fase tonik terjadi ketika aliran listrik melalui otak sehingga menyebabkan hewan kehilangan kesadaran, napas tidak teratur dan kaku otot. Otot yang awalnya kaku, pada fase kronik akan mengalami relaksasi secara bertahap, hewan akan mengalami kejang, urinasi atau defekasi. Dua fase pertama merupakan fase yang terbaik untuk dilakukan penyembelihan, karena pada fase ini hewan kehilangan kesadaran dan tidak peka terhadap rasa sakit. Fase ketiga yakni fase recovery yang ditandai dengan irama napas kembali normal, hewan mulai sadar dan berusaha untuk berdiri.

Babi Landrace Crossbred yang disembelih dengan metode tanpa stunning, akan merasakan sakit selama proses penyembelihan hingga benarbenar hilang kesadaran. Menurut Ulrich-Lai dkk. (2006), rasa sakit merupakan salah satu jenis rangsangan yang dapat menyebabkan hewan mengalami stres. Stres yang dialami hewan akibat rasa sakit mengakibatkan munculnya respon HPA Axis yang akan merangsang sekresi hormon kortisol. Hormon kortisol bekerja menstimulasi terjadinya glukoneogenesis pada hepar, meningkatkan mobilisasi asam amino dari jaringan ekstrahepatik (terutama otot) dan lipolisis pada jaringan adiposa yang menghasilkan gliserol dan asam lemak. Asam amino dan gliserol akan dibawa ke hepar untuk proses glukoneogenesis, sedangkan asam lemak akan dioksidasi menjadi energi melalui jalur oksidasi $\beta$ asam lemak.

Stres juga menstimulasi kerja saraf simpatis sehingga menyebabkan medulla adrenal mensekresikan hormon adrenalin dan noradrenalin (Carrol dkk., 2017). Hormon adrenalin akan bekerja meningkatkan terjadinya glikogenolisis di hati dan otot, serta meningkatkan pelepasan glukosa ke dalam darah (Guyton dan Hall, 2016). Proses glukoneogenesis dan glikogenolisis menyebabkan hiperglikemia sehingga terjadi mekanisme autooksidasi glukosa, glikasi dan pembentukan dikarbonil yang berakibat pada peningkatan produksi ROS (Fakhruddin dkk., 2017).

Tubuh memiliki sistem pertahanan terhadap ROS berupa enzim antioksidan endogen yakni SOD. Enzim SOD merupakan pertahanan terdepan dalam menghadapi kerusakan sel akibat ROS dengan mengkatalis perubahan radikal $\mathrm{O}_{2}^{-}$ $\mathrm{O}_{2}^{-}$menjadi molekul $\mathrm{O}_{2}$ dan $\mathrm{H}_{2} \mathrm{O}_{2}$ (Vaziri dkk., 2003). Enzim SOD pada mamalia dapat dibedakan menjadi SOD1 (cytoplasmic Cu/ZnSOD), SOD2 (mitocondrial MnSOD) dan SOD3 (extracellular $\mathrm{Cu} / \mathrm{ZnSOD}$ ) dengan lokasi yang berbada. Enzim SOD1 dan SOD2 terdapat di dalam sel, sedangkan 
SOD3 terdapat pada exstrasellular matrix, permukaan sel, cairan ekstraselluler dan plasma darah (Fukai dan Ushio-Fukai, 2011).

Penelitian ini menggunakan sampel berupa serum darah untuk uji aktivitas SOD menggunakan metode calorimetric assay. Aktivitas SOD yang tinggi di dalam sampel serum pada penelitian ini ditandai dengan terbentuknya warna kuning pucat sehingga menghasilkan nilai absorbansi yang lebih tinggi tinggi, sedangkan aktivitas SOD yang rendah di dalam sampel serum akan ditandai dengan terbentuknya warna kuning pekat sehingga akan menghasilkan nilai absorbansi yang lebih rendah. Menurut Yu dkk. (2011), serum mengandung zat metabolit dan memberikan nilai sensitivitas yang lebih tinggi dibanding plasma, sehingga serum dianggap lebih potensial digunakan sebagai sampel pengujian dibanding plasma. Pengujian aktivitas SOD dilakukan dengan mereaksikan xanthine dengan xanthine oxidase sehingga terbentuk radikal $\mathrm{O}_{2}^{-} \mathrm{O}_{2}^{-}$dan mengubah substrat menjadi berwarna kuning. Enzim SOD dalam sampel akan mendegradasi radikal $\mathrm{O}_{2}^{-} \mathrm{O}_{2}^{-}$ dan mempengaruhi kepekatan warna kuning yang terbentuk (StressMarq Bioscience Inc., 2019).

Berdasarkan pengamatan data hasil penelitian, diketahui bahwa persebaran data hasil uji aktivitas SOD serum dalam satu kelompok perlakuan cukup beragam, baik pada perlakuan electrical stunning maupun tanpa stunning. Diduga hal ini disebabkan oleh perbedaan respon individu terhadap paparan stres. Perbedaan respon individu terhadap paparan stres disebabkan oleh faktor genetik dan perbedaan kemampuan adaptasi sehingga menyebabkan perbedaan respon sekresi hormon kortisol (Purnama dkk., 2019).

Electrical stunning dapat menurunkan tingkat stres hewan akibat proses penyembelihan, namun memiliki dampak negatif terhadap kualitas daging (Velarde dkk., 2001). Menurut Velarde dkk. (2000), terjadi peningkatan kejadian hemorrhage karkas babi yang disembelih dengan electrical stunning. Aliran listrik akibat electrical stunning dapat menstimulasi pemecahan glikogen otot menjadi asam laktat dan mempercepat proses rigor mortis. Proses tersebut mempercepat penurunan $\mathrm{pH}$ otot saat suhu otot masih tinggi sehingga berdampak pada peningkatan kejadian daging PSE (Fikri dkk., 2017). Electrical stunning yang dilakukan terlalu lama juga dapat menyebabkan denaturasi protein otot sehingga menyebabkan terjadinya drip loss (Channon dkk., 2000).

\section{Kesimpulan}

Dapat disimpulkan bahwa metode electrical stunning dapat menurunkan secara signifikan aktivitas SOD serum babi Landrace Crossbred sebelum disembelih. Metode electrical stunning dilakukan sesuai dengan aspek animal welfare standard pada babi.

\section{Ucapan Terima Kasih}

Peneliti mengucapkan terima kasih kepada Lembaga Penelitian dan Inovasi Universitas Airlangga dan Fakultas Kedokteran Hewan Universitas Airlangga atas bantuan hibah penelitian dengan No.1408/UN3/2019.

\section{Daftar Pustaka}

Adzitey, F. (2011). Mini Review: Effect of PreSlaughter Animal Handling on Carcass and Meat Quality. International Food Research Journal. 18(2): 485-491.

Bergeaud-Blackler, F. (2007). New Challenges for Islamic Ritual Slaughtering: A European Perspective (Forthcoming). Journal Ethnic Migration Study. 33(6): 965-980.

Bourguet, C., Deiss, V., Tannugi, C.C. and Terlouw, E.M.C. (2011). Behavioural and Physiological Reactions of Cattle in A Commercial Abattoir: Relationships With Organisational Aspects Of The Abattoir And Animal Characteristics. Meat Science. 88(1): 158-168.

Carrol. T.B., Aron. D.C., Findling. J.W. and Tyrell, J.B. (2017). Glucocorticoids and Adrenal Androgens. In: Greenspan, F.S and D.G. Gardner. Basic and Clinical Endocrinology $10^{\text {th }}$ ed. Lange Medical Book. USA. pp. 299-308.

Channon, H.A., Payne, A.M. and Warner, R.D. (2000). Halothane Genotype, Pre-Slaughter Handling and Stunning Methods All Influence Pork Quality. Meat Science. 56: 291-299. 
Chulayo, A.Y., Tada, O. and Muchenje, V. (2012). Research on Preslaughter Stress and Meat Quality: A Review of Challenges Faced Under Practical Conditions. Applied Animal Husbandry Rural Development. 5: 1-6.

Dannar, N.N. (2015). Waktu Henti Darah Memancar pada Penyembelihan Sapi dengan Pemingsanan dan Tanpa Pemingsanan [Skripsi]. Fakultas Kedokteran Hewan. Institut Pertanian Bogor. Hal.3.

Del Rio, D., Steward, A.J. and Pellegrini, N. (2005). A Review of Recent Studies on Malondialdehyde as Toxic Molecule and Biological Marker of Oxidative Stress. Journal Nutrition Metabolism Cardiograph Disease. 15(4): 316-328.

[EFSA] European Food Safety Authority. (2006). The Welfare Aspects Of The Main Systems Of Stunning And Killing Applied To Commercially Farmed Deer, Goats, Rabbits, Ostriches, Ducks, Geese, And Quail. EFSA Journal. 326:1-18.

Fakhruddin, S., Alanazi, W. and Jackson, K.E. (2017). Diabetes-Induced Reactive Oxygen Species: Mechanism of Their Generation and Role in Renal Injury. Journal Diabetes Research. 2017: 1-31.

Farouk, M., Al-Mazeedi, H., Sabow, A., Bekhit, A., Adeyemi, K., Sazili, A. and Ghani, A. (2014). Halal and Kosher Slaughter Methods and Meat Quality: A Review. Meat Science. 98(3): 505-519.

Fikri, F., Hamid, I.S. and Purnama, M.T.E. (2017). Uji organoleptis, $\mathrm{pH}$, uji eber dan cemaran bakteri pada karkas yang diisolasi dari kios di Banyuwangi. Jurnal Medik Veteriner. 1(1): 23-27.

Fukai, T. and Ushio-Fukai, M. (2011). Superoxide Dismutases: Role in Redox Signaling, Vascular Function, and Diseases. Antioxidants Redox Signal. 15(6): 1583-1606.

Goba, M.A. (2013). Penanganan dan Distribusi Karkas dan Non Karkas dari Tempat Pemotongan Babi Jeletreng Gunung Sindur Bogor [Skripsi]. Fakultas Peternakan. Institut Pertanian Bogor. Hal.10-11.
Gregory, N.G. (2007). Chapter 12: Meat Quality. In: Animal Welfare And Meat Production. $2^{\text {nd }}$ edn. CABI Publishing. Wallingford. United Kingdom. pp. 213-226.

Guyton. A.C. and Hall, J.E. (2016). Textbook of Medical Physiology. Ed. 13. Elsevier. pp. 780-862.

Hindle, V.A., Lamboij, E., Reimert, G.M., Workel, R.D. and Gerritzen, M.A. (2010). Animal Welfare Concerns During The Use Of The Water Bath For Stunning Broiler, Hens, Ducks. Poultry Science Journal. 89(3): 401-412.

[HSA] Humane Slaughter Association. (2016). Electrical Stunning of Red Meat Animal. https://www.hsa.urg.uk. [13 April 2019]

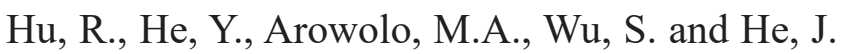
(2019). Polyphenols as Potential Attenuator of Heat Stress in Poultry Production. Journal Antioxidants. 8(67): 3-11.

Kim, G.D., Lee, H.S., Jung, E.Y., Lim, H.J., Seo, H.W., Lee, Y.H., Jang, S.H., Baek, S.B., Joo, S.T. and Yang, H.S. (2013). The Effects of $\mathrm{CO}_{2} \mathrm{CO}_{2}$ Gas Stunning on Meat Quality of Cattle Compared with Captive Bolt Stunning. Livestock Science. 157(1): 312-316.

[OIE] Office International des Epizooties. (2011). Slaughter of Animals Chapter 7.5. Paris (FR): Terrestrial Animal Health Code World Organisation for Animal Health. pp. 332355.

Pleiter, H. (2010). Review of Stunning and Halal Slaughter. Meat and Livestock Australia (MLA). Sydney. Australia. pp. 12-20.

Purnama, M.T.E., Dewi, W.K., Prayoga, S.F., Triana, N.M., Aji, B.S.P., Fikri, F. and Hamid, I.S. (2019). Preslaughter Stress in Banyuwangi Cattle During Transport. Indian Veterinary Journal. 96(12): 50-52.

Purnama, M.T.E., Prayoga, S.F., Triana, N.M., Dewi, W.K., Purnomoaji, B.S., Wardhana, D.K. and Fikri, F. (2020). Oxidative stress parameters in landrace pigs slaughtered by the stunning method. E\&ES. 441(1): 012140 . 
Putra, G.A., Hidayat, E.M. and Thadeus, M.S. (2012). Dampak Penundaan Pemisahan Serum dari Sel Darah Terhadap Hasil Pemeriksaan Kadar Glukosa Darah dengan Metode Heksokinase. Bina Widya. 23(5): 264-270.

Rosenvolt, K. and Andersen, H.J. (2003). Factors Of Significance For Pork Quality-A Review. Meat Science. 64: 219-237.

Sabow, A.B., Sazili, A.Q., Zulkifli, I., Goh, Y.M., Ab Kadir, M.Z.A., Abdulla, N.R., Nakyinsige, K., Kaka, U. and Adeyemi, K.D. (2015). A Comparison of Bleeding Efficiency, Microbiological Quality and Lipid Oxidation in Goats Subjected to Conscious Halal Slaughter and Slaughter Following Minimal Anaesthesia. Meat Science. 104: 78-84.

Sabow, A.B., Goh, Y.M., Zulkifli, I., Ab Kadir, M.Z., Kaka, U., Adeyemi, K.D., Abubakar, A.A., Imlan, J.C., Ebrahimi, M. and Sazili, A.Q. (2018). Electroencephalographic and Blood Parameters Changes in Anaesthetised Goats Subjected To Slaughter Without Stunning And Slaughter Following Different Electrical Stunning Methods. Animal Product Science. 59(5): 849-860.

StressMarq Bioscience Inc. (2019). StressXpress ${ }^{\circledR}$ SOD Activity Kit Quantitative Colorimetric Measurement of Superoxide Dismutase Activity Catalog SKT-214. https://www. stressmarq.com/products/assay-kits/sodactivity-kit-skt-214/. pp. 1-20

Surai, P.F. (2016). Antioxidant Systems in Poultry Biology: Superoxide Dismutase. Journal Animal Research Nutrition. 1(8): 1-17.

Ulrich-Lai, Y.M., Xie, W., Meij, J.T., Dolgas, C.M., Yu, L. and Herman, J.P. (2006). Limbic and HPA axis function in an animal model of chronic neuropathic pain. Physiology Behaviour. 88(1-2): 67-76.
Vaziri, N.D., Michael, D., Nathan, D.H., Boroujerdi-rad, L. and Sindhu, R.K. (2003). Oxidative Stress and Dysregulation of Superoxide Dismutase and NADPH Oxidase in Renal Insufficiency. Kidney International. 63: 179-185.

Velarde, A., Gisperta, M., Faucitanoa, L., Mantecab, X. and Diestre, A. (2000). The Efect of Stunning Method on The Incidence of PSE Meat And Haemorrhages in Pork Carcasses. Meat Science. 55: 309-314.

Velarde, A., Gispert, M., Faucitano, L., Alonso, P., Manteca, X. and Diestre, A. (2001). Effects of The Stunning Procedure and The Halothane Genotype on Meat Quality and Incidence of Haemorrhages in Pigs. Meat Science. 58(3): 313-319.

Warner, R.D., Greenwood, P.L., Pethick, D.W. and Ferguson, D.M. (2010). Genetic and Environmental Effects on Meat Quality. Meat Science. 86(1): 171-183.

Yu, Z., Kastenmuller, G., He, Y., Belcredi, P., Moller, G., Prehn, C., Mendes, J., Wahi, S., Roemisch-Margi, W., Ceglerek, U., Polonikov, A., Dahmen, N., Prokisch, H., Xie, L., Li, Y., Wichmannn, H.E., Peters, A., Kronenberg, F., Suhre, K., Adamski, J., Illig, T. and Wang-Sattler, R. (2011). Differences between Human Plasma and Serum Metabolite Profiles. Ploss One. 6(7): 1-6.

Zivotofsky, A.Z. and Strous, R.D. (2012). A Perspective On The Electrical Stunning Of Animals: Are There Lessons to be Learned From Human Electro Convulsive Therapy (ECT). Meat Science. 90(4): 956-961. 